\title{
A META-ANALYSIS OF THE IMPACT OF PRIVATIZATION ON FIRM PERFORMANCE
}

\begin{abstract}
Purpose: Despite the vast literature on privatization, the relationship between change of ownership and performance is not clear. The purpose of the paper is to understand why we find divergences between the empirical results of papers analyzed.

Design: We apply a meta-analysis to a sample of 60 empirical studies that analyze the performance of privatized companies. We check whether different results on performance can be explained by the method of privatization and the level of development of the country of privatized companies.

Findings: Our findings indicate that companies privatized by public offerings obtain a better performance than companies privatized using other methods, such as private sale or voucher privatization, and do not support the common-place assumption that privatization in developing countries does not improve financial performance.

Originality/value: The study contributes to the literature on privatization because it adds new empirical evidence about the privatization programs and it first applies a metaanalysis to a sample about privatization on state owned companies. We discuss theoretical and managerial implications and offer suggestions for future research on privatization.
\end{abstract}

Keywords: Privatization; meta-analysis; performance; state governments Article Classification: Research paper 


\section{1.- Introduction}

The privatization of state-owned enterprises (SOEs) has become a common process all over the world and was considered a major component of the New Public Management -NPM-(Broadbent and Guthrie, 1992; Durant and Legge, 2001; Durant and Legge Jr, 2002; Hodge, 2006; Hood, 1991; Lane, 2000; Löffler and Bovaird, 2009; Peters, 1996; Pollitt and Bouckaert, 2000; Torres and Pina, 2002 among other authors). In the framework of this doctrine, privatizations are expected to correct inefficiencies associated with the public sector. Since the beginning of this process, in the eighties, there have been numerous studies about the privatization policies carried out in different countries, analyzing their advantages and disadvantages and their impact on the economy. Although most cross-sectional studies give a considerable advantage to private ownership, the cumulative evidence is not conclusive (Villalonga, 2000). On average, there is an improvement in firm performance after privatization, but the variance across empirical tests is substantial. Despite the efforts of previous research, the question remains open.

There are several potentially important theoretical moderators of the privatizationperformance relationship. Given the prominence of privatization as a determinant of performance differences, the initial evidence suggesting that the empirical evidence is mixed, and theory suggesting that there are important moderators of this relationship, a meta-analysis designed to clarify extant evidence seems both timely and warranted. Therefore, we present a meta-analysis to shed light on how the change of ownership impacts on the performance of privatized companies. Meta-analysis quantitatively aggregates prior studies' empirical findings to detect whether a relationship exists and to estimate the magnitude of the effect by taking into account study artifacts, such as sampling and measurement error (Hunter and Schmidt, 1990). Meta- analysis also 
allows investigation of moderators that help explain why results vary systematically among studies of the same relationships. Although Bel and Fageda (2009) apply metaanalysis to study privatization in the local sphere, to our knowledge, this methodology has not so far been applied to the study of the privatization of SOEs. To carry out the meta-analysis, we select publications that analyze the pre- and post-performance of privatized companies. Firstly, we carry out the funnel asymmetry test proposed by Stanley and Doucouliagos (2010) and, secondly, a meta-regression analysis (MRA) method has been run to determine the effect of the method of privatization and the level of development of the country on financial performance.

The purpose of the paper is to understand why we find divergences between the empirical results of papers analyzed. For this, we study whether differences in the financial performance of privatized companies are explained by two potential moderators (a) the method of privatization and (b) the level of development of the country. Overall, our findings indicate that the method of privatization is a determinant of the performance of privatized companies and results contradict the common-place assumption that privatization in developing countries does not improve the financial performance.

The paper is organised as follows. The next section contains the background to the privatization processes. Section 3 presents a review of the literature on the relationship between privatization and performance. Section 4 details the method used in the study and describes the data and variables used in the analysis. Section 5 presents our empirical results, Section 6 the discussion and Section 7 our conclusions. 


\section{2.- Background}

Both nationalization and privatization are the outcome of historical processes. Government ownership, through nationalization, has been perceived by some authors as necessary to promote growth. This ownership is higher in countries with low levels of per capita income, backward financial systems, interventionist and inefficient governments, and poor protection of property rights (La Porta et al., 2001). Another reason for nationalization is resentment towards the foreigners who had owned many of the largest firms in developing countries. Politicians consider that the state should control strategic economic sectors, such as steel production and defence. However, the political economy view indicates that governments acquire control of enterprises to provide employment, subsidies, and other benefits to supporters, who return the favour in the form of votes ${ }^{1}$. There is extensive literature about the reasons given by governments, politicians and national and international institutions to justify privatization processes. Yarrow (1999) listed the following reasons: enhancing efficiency by means of the introduction of competition and by obtaining resources in financial markets; reducing the deficit and the public debt; decreasing trade union influence; transferring the decision-making process in the markets of goods and services from the public to the private sector; encouraging a popular capitalism; empowering employees by selling them company shares; and redistributing social wealth.

Theoretical reasons for contrary findings across studies include the modifications in the corporate governance system during the privatization process. The OECD (2001) considers that the privatization of SOEs has been one of the most important channels for improving corporate governance, which is a key element for enhancing economic efficiency and investor confidence. Good corporate governance should provide proper

\footnotetext{
${ }^{1}$ For more detail, see the works of La Porta et. al (2001) and Megginson and Netter (2001), among others.
} 
incentives for the board and management to pursue objectives that are in line with the interests of the company and of shareholders and should create trust in order to promote an efficient and transparent market economy. The change of the ownership structure has required modifications in the mechanisms of corporate governance of privatized companies. In these companies, governance depends on the effectiveness of relations between interest groups that control the strategic management and the performance of the company. Corporate governance has to do with the agency problem and its fundamental question is how to assure investors that they get a return on their financial investment. To boost the development of corporate governance and reach this objective, it is necessary the separation of owners and managers and the expansion of capital markets, derived from the increase of quoted firms.

With globalization, institutional investors force companies to comply with the rules of transparency and corporate governance, as institutional investors acquire shares of companies to maintain shares in the long run (Megginson, 2005). Creating a satisfactory corporate governance system generally involves changing a nation's corporate and securities laws, strengthening the listing and disclosure requirements for its stock exchanges, enhancing the independence and competence of the national judiciary and establishing a regulatory regime capable of balancing the competing claims of managers, outside shareholders, and creditors. The privatization process influences internal and external mechanisms of CG (Faraci, 2001). Internal governance mechanisms include ownership concentration, board composition, executive compensation, top management replacement, the monitoring of executive decisions and the protection of outside investors. External governance mechanisms refer to the effectiveness of a market for corporate control that may permit the purchase of the firm when it is underperforming. Other corporate governance mechanisms are the legal 
system and codes of good governance. The country's legal system must force managers to feel the discipline of the capital market (D'Souza et al., 2001; La Porta et al., 2000)². Markets affording greater shareholder protection are consistently larger and more efficient. Codes of good governance are a set of best practice recommendations about the structure of the boards of directors and act as a substitute for deficiencies in the protection of shareholders in the legal system (Cuervo, 2002).

In the privatization context, all these mechanisms are very important and the government should prevent the newly-created shareholders from being expropriated by the managers of privatized companies (Bortolotti et al., 2003). Where the law affords weak protection to shareholders, governments are more reluctant to relinquish control of SOEs to avoid opportunist behavior on the part of privatized firms and privatization efficiency is lower. Dharwadkar et al. (2000) argue that weak governance and a limited protection of minority shareholders intensify traditional principal-agent problems ${ }^{3}$. Therefore, post privatization performance improves when corporate structures are introduced into the companies.

In developing countries, the relationship between privatization and corporate governance has been analyzed by Boubakri et al. $(2004,2005,2008)$, among others. These authors find that the change of ownership induces modifications in the corporate governance of firms and improves performance. The biggest improvements in performance are associated with developed stock markets and where laws protect shareholder rights. Nestor and Mahboobi (2000) assert that better incentives systems and governance mechanisms produce higher efficiency in privatized companies. If

\footnotetext{
${ }^{2}$ La Porta et al. (2000) note that the protection of shareholders' legal rights varies significantly across countries. Shareholders in countries with an English common law tradition benefit from much stronger legal protection than those living in nations with French civil law systems.

${ }^{3}$ These problems have relationship with issues of managerial discretion and expropriation, which occurs when large owners assume control of the firm and deprive minority owners of the right to appropriate returns on their investments.
} 
companies incorporate a corporate governance system similar to private companies, they improve their performance whether they are privatized or not. This is because the SOEs' system of governance experiences more dysfunctions due to interference from politicians (Alexandre and Charreaux, 2004). However, Cragg and Dick (1999) assert that the privatization of companies does not lead to changes in their corporate governance because the governments transform SOEs into giant bureaucracies.

Although the agency and public choice theories defend that privatization improves the performance of companies ${ }^{4}$, many studies do not agree with this assertion ${ }^{5}$. There is considerable debate about whether the efficiency and productivity of a SOE depends more on regulation and competition in the market or on ownership (Ramamurti, 1997; Vickers and Yarrow, 1988; Vining and Boardman, 1992; Yarrow et al., 1986; Zohlnhöfer et al., 2008). According to Vickers and Yarrow (1991) and Newbery and Pollitt (1997), competition is one of the main components of improvements in the performance of privatized companies. Liberalization, more than privatization, forces public companies to be more efficient. Empirical studies like Megginson et al. (1994) and La Porta and Lopez-de-Silanes (1999) assert that there are significant differences between the performance of companies that operate in competitive and non-competitive markets. In these studies, it can be observed that all companies improve their performance after being privatized; but, if the market is competitive, the benefit will be higher.

\footnotetext{
${ }^{4}$ See Arocena and Oliveros (2012), Boardman et al. (2002), Bortolotti et al. (2002), Boubakri and Cosset (1998), D'souza and Megginson (1999), Eckel et al. (1997), La Porta and Lopez-de-Silanes (1999), Megginson and Sutter (2006), Megginson et al. (1994), Prior and Surroca (2005), Qi et al. (2000), Rodríguez et al. (2007).

${ }^{5}$ See Arcas and Bachiller, 2008; Bacchiocchi et al., 2005; Boussofiane et al., 1997; Chen et al., 2007; Frydman et al., 1999; Martin and Parker, 1995; Omran, 2009; Parker and Hartley, 2006; Pejovich, 2005; Villalonga, 2000; $\mathrm{Wu}, 2006$; Bachiller, 2009.
} 
Figure 1 summarizes factors that boost the privatization process and its main results. Key elements such as globalization, liberalization, regulation, competition, restructuring of privatized companies and changes in corporate governance systems are causal factors that influence post privatization performance. Results of the privatization process may be observed in the economy (more competitive and developed markets and modernization of corporate governance, among others) and in the companies (higher efficiency and performance).

[Insert Figure 1 about here]

\section{3.- Theory and literature review}

\section{Method of privatization}

The decision about which privatization method to employ is not straightforward. Political factors, like the ideology of the government in question of market and regulation, and economic factors, like the financial position of SOEs and the conditions of capital markets, are involved in the process. Governments chose privatization by public offer and established a regulation to increase the confidence of potential investors and guarantee that the capital markets were appropriate for investing in these companies (OECD, 1998).

The adoption of privatization programs seeks to promote the so-called popular capitalism, that is, the democratization of capital markets through the participation of citizens in privatization processes. The purpose of this is to decrease ownership concentration, which can have a negative effect on firm performance (Wang and Shailer, 2015), to strengthen a nation's governance systems and to lead to significant 
improvements in financial systems and changes in the market regulation to create more competitive and efficient markets. Privatization programs have forced governments to improve effective governance systems so that the change of ownership of SOEs is perceived as both an economic and a political success (Megginson, 2005; Tian and Estrin, 2008). This is more complex than simply selling SOEs because it implies that many rules and institutions have to change simultaneously. Concern about the security issues of capital markets rose with the privatization process and the law has tried to strengthen the protection of minority shareholders (Corrado and Zollo, 2006).

Privatizations through initial public offering (IPO) have fomented the development of capital markets (Megginson et al., 2004). The sale of shares of SOEs have tended to be underpriced to attract the participation of investors (Dewenter and Malatesta, 1997; Boutchkova and Megginson, 2000; Von Eije and Megginson, 2008), who consider that privatized firms are 'too big to fail' and whose regulatory framework protects them. Larger and more profitable SOEs are more likely to be privatized through capital markets, while governments that have less state control over the economy tend to privatize SOEs via asset sales. Quoted companies generate an economic benefit from the increase in liquidity that they provoke in capital markets. Moreover, the public trading of shares establishes the possibility of takeover by outsiders and the threat of a takeover is another management control mechanism. These market operations may stimulate managers to achieve greater efficiency and to avoid being acquired by another company. A major consequence of privatization is that privatized companies can be targets of takeovers and mergers.

From these explanations, it can be deduced that the level of development of capital markets is a key determinant of post-privatization efficiency gains (Boubakri and Cosset, 1998). More developed markets facilitate access to private debt and equity, 
which allows a more far-reaching modernization and restructuring of companies. Companies whose shares are traded in more sophisticated and active markets can obtain greater performance improvements from the privatization process.

Taking all the above into account, we posit that:

H1: The method of privatization is a determinant of the performance of privatized companies.

\section{Developed and developing countries}

The determinants of privatization performance are different in developed and developing countries (Boubakri et al., 2005; D’Souza et al., 2005). The institutional framework is weaker in developing countries, which provides limited investor protection (Boubakri et al., 2008). When the law affords weak protection to shareholders, governments are more reluctant to sell SOEs to avoid opportunist behavior from privatized firms, potential investors do not trust privatization processes and their effectiveness, consequently, is lower.

In developing economies, the costs by the limited competition due to technology (economies of scale, network externalities) are internalized by the governments of these countries and manifested during the privatization. Traditional agency problems may be pronounced because of underdeveloped institutional infrastructures, the lack of effective governance mechanisms, poor enforcement of property rights and underdeveloped capital markets without effective control (Zahra et al., 2000). The evidence shows that privatization produces better performance in countries where stock market development and trade liberalization preceded privatization (Boubakri et al., 2005). Dharwadkar et al. (2000) argue that principal-agent problems are linked to issues of managerial 
discretion and expropriation, which occur when large owners assume control of the firm and deprive minority owners of the right to appropriate returns on their investments.

In developing economies, privatization is a complex economic and political process (Frydman et al., 1999). Privatization programs are much larger than in developed countries and these processes are part of a wider reform of political and economic systems. Restructuring the company may lead to a successful privatization process (Boussofiane et al., 1997; Alexandre and Charreaux, 2004; Cavaliere and Scabrosetti, 2008; Chong and Galdo, 2007; Cragg and Dyck, 1999). However, the literature shows that the state has continued to hold shares in the vast majority of privatized companies (Aussenegg and Jelic, 2007) and management has not been replaced in these companies. The post-privatization ownership structure tends to be mainly concentrated in the hands of local institutional investors, which could hinder stock-market growth and the replacement of the management. So, the newly privatized enterprises have difficulty carrying out the restructuring with the existing management and, as Dyck (1997) asserts, face additional costs in purchasing managerial skills on the labor market because of the adverse selection problem.

Consequently, our second hypothesis is:

H2: Performance of privatized companies differs in developed and developing countries.

\section{4.- Meta-analysis data}

\subsection{Selection of studies}

To date, more than sixty papers have studied the relationship between privatization and performance. However, they contain conflicting empirical results that come from study characteristics that affect the privatization-performance relation. We only focus on the 
financial performance because the non-financial performance (e.g. quality and effectiveness) has not been analyzed by a sufficient number of studies to warrant a robust meta-analysis.

In order to identify relevant studies, our literature search responds to the combination of keywords "privatization and performance" and the search was completed in October, 2014. Our meta-analysis includes articles published in academic journals in the fields of Economics, Administrative Science, Finance and Public Administration, non-published papers and working papers ${ }^{6}$. The databases used to discriminate the articles are the ISI Web of Knowledge and Google Scholar.

We selected the empirical studies for inclusion in the meta-analysis on the basis of a set of criteria. First, we included only empirical studies that reported sample sizes and rstatistics of effects, such as correlation coefficients (Rosenthal, 1991). In the Metaanalysis, the most widely used metric is the Pearson correlation coefficient $r$, which indicates the association between ownership and performance after controlling for other factors. The use of $r$ as the effect size is appropriate, it is scale-free and indicates both the direction and magnitude of the relations (Lipsey and Wilson, 2001). Second, the paper had to contain at least one relationship between privatization and performance. The selection yielded a total of 60 studies, dated 1989-2014, with quantitative and comparable data on financial performance and privatization. The sample covers 48 countries and data years 1961-2010.

Table 1 shows general information on all the studies included in our sample.

$$
\text { [Insert Table } 1 \text { about here] }
$$

\subsection{Publication status}

\footnotetext{
${ }^{6}$ Almost all the authors analysed have published their studies in journals; only a few of the articles are unpublished.
} 
As far as we know, our sample includes all studies that analyze the performance of privatized companies and explain their determinants factors. Given that meta-analysis requires as many papers as possible, we have included non-published papers and working papers with comparable and homogeneous statistics.

\subsection{Publication bias}

Publication bias or file-drawer problem arises when researchers, referees or editors have a preference for publishing results that either support a particular theory or are statistically significant. This is particularly strong in fields that show little disagreement concerning the correct sign of the parameter. As a consequence, estimates supporting the theory are more likely to be published, whereas insignificant results or results showing an effect inconsistent with the theory tend to be underrepresented in the literature (Valickova et al., 2014).

Following Stanley and Doucouliagos (2010), we regress the estimated effect size on its standard error. Table 2 reports the results of the funnel asymmetry test for each different performance measure. For measures of financial performance, profitability, efficiency, investment, leverage, output and dividends, the constant is non-significant, which indicates no publication bias. For employment and management, the constant exhibits publication bias. These findings suggest that conclusions based on a review of published data could be incorrect. The coefficient 1/SE measures the privatization-performance effect, corrected for publication selection. The statistically significant estimation of this coefficient for profitability, efficiency, investment, output and dividends indicates that the literature identifies, in most cases, a positive link between privatization and these measures of performance. This relationship is clearer for efficiency and profitability, whose $\mathrm{p}$-value denotes significance at the $1 \%$ level. For leverage, this coefficient is not 
significant, which indicates a lack of relationship between this magnitude and privatization.

[Insert Table 2 about here]

\section{5.- Methodology}

\subsection{Estimating effect size}

We calculate the effect size as the correlation coefficient $r$. For studies that do not report $r$ statistics, that is, studies that report $Z$ statistics from the Wilcoxon test and Student's ttest, we compute $r$ as follows (Rosenthal, 1991):

$$
r=\frac{z}{\sqrt{n}}
$$

where $n$ is the sample size.

Table 3 shows descriptive statistics of correlation coefficients for the relationship between privatization and performance. For each study, we select the coefficients of different measures of financial performance: profitability, employment, efficiency, investment, leverage, output, management and dividends. We follow the criteria of papers considered into the meta-analysis about the relationship between these measures and the performance. Papers included in the meta-analysis use ROA, ROE and ROS as profitability measures. Therefore, the relationship between profitability and performance is considered positive. The efficiency is measured as the ratio sales/profit over employees and as a efficiency index provided by the DEA model. The relationship between efficiency and performance is positive. The number of employees is used as 
measure of employment. Its relationship with performance is considered positive. Papers use the ratios investment over sales and over employees as Investment measures. A positive relationship between investment and performance is indicative of improved performance. The leverage is mainly measured as the ratio debt over assets; therefore, the relationship with performance is considered negative. The variable real sales (output) has a positive relationship with the performance. Papers have defined differently the variable management (i.e. process innovation, organizational innovation, strategic renewal). For all papers, this variable has a positive relationship with performance. Papers included in the meta-analysis use dividends payout and the ratio dividends over sales as dividend measures. Therefore, the relationship between this measure and performance is considered positive. In sum, a positive (negative) sign for profitability, employment, efficiency, investment, output, management and dividends (leverage) is considered an improved (non-improved) performance.

[Insert Table 3 about here]

We carry out the Hunter and Schmidt (1990) meta-analysis to obtain comparable effects and convert them to a common metric. This methodology uses statistical aggregation techniques for cumulating correlations and correcting for various study artefacts in order to estimate the true score correlation $(\rho)$ between privatization and performance. When one study offered various correlations between a performance measure and privatization (correlations, for example, due to various measures of independent variables), we use one correlation coefficient per study (the mean correlation coefficient) in the meta-analysis in order to maintain independence between 
observations (Hunter and Schmidt, 1990). For each association between the performance variable and privatization, we first calculate the weighted mean correlation coefficient $\left(\overline{\mathrm{r}}=\Sigma \mathrm{N}_{\mathrm{i}} \mathrm{r}_{\mathrm{i}} / \Sigma \mathrm{N}_{\mathrm{i}}\right)$, the total observed variance $\left(\mathrm{S}_{\mathrm{r}}^{2}=\Sigma \mathrm{N}_{\mathrm{i}}\left(\mathrm{r}_{\mathrm{i}}-\bar{r}\right)^{2} / \Sigma \mathrm{N}_{\mathrm{i}}\right)$ and the sampling error variance $\left(\mathrm{S}_{\mathrm{e}}{ }^{2}=\left(\mathrm{r}_{\mathrm{i}^{-}} \bar{r}^{2}\right)^{2} \mathrm{k} / \Sigma \mathrm{N}_{\mathrm{i}}\right)$, where $N_{i}$ is the number of observations in each sample, $r$ the effect size for sample $i$ and $k$ the number of effect sizes. Larger sample sizes are given more weight in order to reduce sampling error, which declines as sample size increases.

To evaluate whether the empirical correlations are homogeneous, we use two tests: (1) the $75 \%$ rule, according to which, if $75 \%$ of the observed variance across studies can be explained by sampling errors $\left[(100) \mathrm{S}_{\mathrm{e}}{ }^{2} / \mathrm{S}_{\mathrm{r}}{ }^{2} \geq 75\right]$, we can conclude that there is no true variance in the studies and, thus, the association is un-moderated and homogeneous; and (2) the Q statistic:

$$
\mathrm{Q}=\mathrm{k}\left(\mathrm{S}_{\mathrm{r}}^{2}\right) /\left(\mathrm{S}_{\mathrm{e}}{ }^{2}\right)=\mathrm{N} \mathrm{S}_{\mathrm{e}}{ }^{2} /\left(1-\bar{r}^{2}\right)^{2}
$$

where $\mathrm{k}$ is the number of effect sizes included in the analysis, $\mathrm{S}_{\mathrm{r}}^{2}$ the total observed variance, $\mathrm{S}_{\mathrm{e}}{ }^{2}$ the sampling error variance, $\mathrm{N}$ the total sample size of the effect sizes and $\bar{F}$ the mean correlation coefficient. The statistical function of $\mathrm{Q}$ has a chi-square distribution with k-1 degrees of freedom, and a significant $Q$ would indicate rejection of the null hypothesis of homogeneity.

\subsection{The meta regression model}

We carry out a meta-regression, taking the relation between privatization and performance as the dependent variable and the method of privatization, the industry and the kind of country analyzed as independent variables. For the meta-analysis, we use the Fisher's $\mathrm{Z}$ transformation of correlation coefficient between privatization and performance obtained from the studies as the dependent variable in the meta-regression. 
These values are indicative of different measures of financial performance above mentioned: profitability, employment, efficiency, investment, leverage, output, management and dividends. In particular, we estimate the following relationship:

Financial Performance $=\mathrm{f}($ Method privatization, Developing, Industry, D70, D80, D90,

$$
\text { Percentage) (1) }
$$

where

- Method of privatization is a dummy variable that takes value 1 when the study refers to companies privatized by IPO and 0 otherwise.

- Developing is a dummy variable that takes value 1 when the study analyzes companies privatized in developing countries and 0 , in developed countries.

- Industry is a control variable that takes value 1 when the study analyzes companies from several industries and 0 otherwise.

- Percentage of privatization: dummy variable to control for any impact on performance due to the percentage of privatized shares (full-value 1- or partial privatization).

- Decade of privatization: dummies variables that control for the decades in which the privatization operations have been carried out. The variables D70, D80 and D90 are introduced into the regression to indicate whether the company was privatized in the seventies, eighties or nineties, respectively; the value is equal to one in the affirmative case and zero otherwise. The base is D60.

Table 4 shows descriptive statistics of the independent variables.

\section{6.- Analysis of results}

We analyze the association between privatization and performance separately in Tables 5,6 and 7. 
In Table 5, we offer the results of the meta-regression analysis for each different performance measure whose dependent variable is the Fisher's $\mathrm{Z}$ transformation of correlation coefficient and the independent variables are method of privatization (public offer or others) and developing (kind of country, developing or developed) ${ }^{7}$. The variables introduced into the model as control variables are Industry, Decade of privatization (70-90) and Percentage. The F value is high enough to conclude that the variables with a significant $t$ have a meaningful influence on the $Z r$.

The results show a positive and significant coefficient for method of privatization in the profitability and efficiency models, which means that this variable is correlated with performance. Therefore, the method of privatization is an explanatory factor of postprivatization performance and companies privatized via IPO obtain a better profitability and efficiency than those privatized via other methods. However, results indicate that companies privatized via IPO invest less than companies privatized by private sale.

The variable developing is also significant for profitability, efficiency, investment and output. The privatization process carried out in developing and developed countries differs. Results indicate that profitability, efficiency, investment and output increase in developing countries. That is, companies privatized in developing countries obtain a better performance than those privatized in developed countries.

The results show a non-significant coefficient for $D 70$ and $Y 90$, which means that these variables are not correlated with performance. The variable industry is only significant in the output dimension, which indicates that privatizations in only one industry lead to an improvement in output.

\footnotetext{
${ }^{7}$ The regression has not been carried out for the variables management and dividends due the lack of degrees of freedom.
} 
The coefficient of the variable Y80 indicates that privatizations carried out in the eighties are explanatory factors of post-privatization performance. The coefficient of the variable percentage indicates that full privatization leads to better profitability, less investment and less output. Therefore, this coefficient does not allow us to conclude that full privatization generates a better performance.

We also carry out the Levene test to calculate the variances in ANOVA (Table 6). Levene's test has been used to assess the homogeneity of variances for each financial measure calculated for two groups and does not require normality. It tests the null hypothesis that the groups' variances are equal, that is, there is homogeneity of variance or homoscedasticity. If the resulting p-value of Levene's test is less than the specify significance level, we can reject the null hypothesis and conclude that there is significant differences between groups, and so the ANOVA test conducted does no satisfy the homogeneity of variances assumption.

[Insert Table 6 about here]

As we can see, the results of the ANOVA indicate that the profitability, efficiency and investment of companies privatized through IPO has been different to the performance of companies privatized using other methods. So, the method of privatization influences performance. Differences are also significant for the variable developing; studies that analyze developed countries obtain different results to studies that analyze developing countries for profitability and investment.

Table 7 shows the results of the overall meta-analysis for the association between all measures of performance and privatization.

[Insert Table 7 about here] 
As we can see, global performance is positively and significantly associated with privatization. We cannot assume homogeneity since homogeneity tests are rejected. We also divide the sample into the different measures of performance. The relationships between privatization and profitability, efficiency, investment, output and dividends are positive and significant. This means that privatization has improved these financial measures. These results confirm the postulate of privatization theory which suggests that a change of ownership from public to private leads to improvements in performance. On the other hand, the association between performance and leverage is negative and significant. This indicates that privatization is inversely related to leverage.

\section{7.- Discussion}

In spite of the multitude of studies about the relationship between change of ownership and financial performance, the lack of consensus in the results leaves this debate open. This is why this study is motivated by three questions: whether, how and under which circumstances privatization benefit the performance of the firms. The conflicting evidence on this topic limits research development in this field and the use of one type of measure rather than another limits the study of performance. The high variance in previous empirical findings point to the existence of contextual moderators. Following an evidence-based research approach, we empirically synthesized research results of 60 empirical studies about the relationship of privatization and performance by carrying out a meta-analysis. This methodology allows us to obtain a quantitative generalization, identify the factors that influence the relationship between privatization and performance and to understand why we find divergences between the empirical results of papers analyzed. 


\section{1.- Theoretical implications}

Theoretical debates regarding effects of privatizations center on how these programs influence performance. A prominent stream of literature proposes that private ownership have advantages in comparison to public ownership when operating in environments of competitive market structure (Vickers and Yarrow, 1988). Further research points to two important effects that could explain a positive performance impact of privatizations on firms: the method of privatization and the development of the institutional infrastructure and governance mechanisms (Zahra et al., 2000).

The meta-regression shows that privatization through IPO seems to play an important role for performance effects of privatizations. Specifically, the relationship between privatization and profitability and efficiency is significantly stronger if the method is IPO. This result is coincident with D'Souza et al. (2001), Von Eije and Megginson (2008) and Arcas and Bachiller (2010), among others. Privatizations through IPO play an active role in corporate governance and governments structure IPO to maximize political and economic benefits at the expense of revenue maximization (Jones et al., 1999) and care whether their citizens have a positive investment experience after purchasing shares os SOEs being privatized. In sum, they take care in designing IPOs and are concerned that the stock markets are fair and honest markets (Megginson, 2005). To this, governments have adopted new regimes of corporate and securities law, establishing regulatory bodies to oversee privatized utilities and protect investors. The discipline of capital markets explains why IPOs are a more effective method of privatization than private sale and vouchers for improving firm performance. The threat of a takeover -when the company is not efficient enough- and the risk of bankruptcy are higher for quoted companies than for non-quoted companies. Furthermore, public equity markets increase managerial effort and accountability due to the information 
requirements of market regulators. However, this results should be interpreted with caution as governments might be more proficient in selecting the more promising firms as target of privatizations.

If we isolate the effect that privatizations have on investment the advantages from IPO vanishes. This finding indicates that proposed benefits associated with privatizations might be partially offset by disadvantages in the field of investments. For example, in the telecommunications sector the investment is necessary for technological progress and an increase in the services and quality delivered by these companies. Investment in infrastructure is crucial for generating growth, increasing competitiveness and improving service quality. Companies that invert retain market share and be more profitable in the long run, especially in markets characterized by networks. Furthermore, the investment in technology leads to an increase in service quality (Thatcher and Pingry, 2004). The institutional environment also influences the development of investment. If incentive regulation is appropriate, the service quality improves because companies invest more to keep their market position and the network expands. When competition is higher, privatized companies, motivated by a strong desire to retain market share in a competitive industry, choose to invest more in providing end-users with high service quality and use new techniques to differentiate themselves (Banerjee, 2003). Regulators must eliminate restrictions on entry to encourage the creation of modern networks (Woroch, 2000) and promote competition, investment and innovation. Taken together, our results raise doubts whether there is - on average - a positive effect of privatization through IPO.

Although privatization is a complex process in developing countries (Frydman et al., 1993) because of underdeveloped institutional infrastructures, the lack of effective governance mechanisms and poor enforcement of property rights (Dharwadkar et al., 
2000; Zahra et al., 2000), our results show the better performance of privatized companies in developing than in developed countries. Differences between government controls and regulation in developing and developed countries can explain why privatization acts differently in the two kinds of countries ${ }^{8}$. SOEs in developing countries do not have sufficient resources because of the weak state institutions which underfund infrastructure. These companies are more exposed to the corruption of their governments; therefore, the transfer of ownership to private hands may bring greater benefits in developing countries. Megginson (2005) assert that, in communist countries, deep reforms in corporate governance and the protection of creditors and investors led to superior economic performance, indicating the developing countries able to implement needed legal and regulatory changes were also able to recover most rapidly from the decline in output that all transition economies experienced after the collapse of communism. Moreover, the differences of rates of economic growth between developing and developed countries also explain why privatization in developing countries is a useful tool to improve firm performance. This result is consistent with Boubakri and Cosset (1998) and Megginson and Sutter (2006) who note strong performance improvements for companies operating in developing countries. The empirical evidence in developing economies shows that private ownership is better than diffuse ownership and foreign ownership is better than domestic. The identity of new owners is more important and the impact of post-privatization ownership on the performance is much greater than in non-developing economies (Megginson, 2005). When the control of SOEs is transferred to private holders, investment funds and foreign investors, most value is created due to managers are more effectively oversighted and disciplined by improved corporate governance regimes. The

\footnotetext{
${ }^{8}$ We must be cautious since, in developing countries, where the regulation of infrastructure industries may be absent, the performance measures do not always show whether a reduction in availability or quality has occurred after privatisation.
} 
appointment of new managers is associated with significant improvements in profit margin and labor productivity, particularly if the managers are selected by private owners (Claessens and Djankov, 1999).

It must be highlighted that privatization programs have been accompanied by liberalization processes in these countries which are much larger and have not always happened in developed countries. This indicates that governments have modernized a nation's corporate governance system to promote transparent markets by introducing incentives systems in companies and creating arrangements that are conducive to effective governance. In line with the property rights theory, our findings suggest that privatization have replaced political managers in order to create an independent governance system in the companies in these countries. Investors acquire shares will restructure the company in order to adapt it to the new competitive environment and to recover their investment and obtain a higher profitability.

\section{2.- Managerial implications}

Findings presented in our study indicate that privatization thought IPO has a positive effect on the performance. Much of the positive performance effects are due to improvements in the corporate governance system and the discipline of capital markets, which can be value-creating especially with regard to firm growth. As D'Souza et al. (2001) assert, the public trading of shares of privatized companies in capital markets increases their efficiency if privatization is linked to the possibility of a takeover by outsiders, disciplines managers and allows linking compensation to performance. So, when shares are traded in public equity markets, managerial effort and accountability increase. The change of ownership means that managers have to justify their actions to new, private shareholders and are exposed to the risk of being replaced by more efficient managers. Moreover, disclosure requirements related to the IPO improves the 
performance of privatized firms. In quoted companies, the uncertainty is reduced due to more information becomes available and information asymmetries decrease (Rosenbusch et al., 2013). Our findings provide further support to the theory that privatizations provide value for public firms. If access to substantial financial capital is available through other means rather than the public markets, the value that privatizations can provide likely diminishes. However, we also found that companies privatized in capital markets do not invest more than when they are SOEs. This suggest that the quality of delivered services may be deteriorated after privatization. Although privatization has reduced the role of the State in the production of good and services, the growing demand for more and better quality infrastructure services and technological developments in sectors as the telecommunications makes necessary to establish regulations to improve quality. Hence, economic regulators should choose standards according to consumers' valuation when they establish standards of quality regulation.

Organizational change is another relevant effect of the privatization process. New management systems incorporate efficiency and customer orientation as objectives of the firms (Clarke and Pitelis, 1993). However, this can be done without the necessity of changing ownership. This is known as corporatization, that is, the company restructures itself and changes its governance to imitate private firms' management and to be more efficient. The company incorporates incentive contracts, remuneration systems and changes in the corporate governance to guarantee transparency, which has a positive impact on the performance of public companies.

\section{3.- Limitations and Future Research}

The presence of heterogeneity in the meta-analysis indicates that other moderators determine the performance of privatized companies, including the regulatory framework. However, most studies included in the meta-analysis aggregate companies 
from different countries and do not distinguish between regulated and non-regulated companies.

The likelihood that a particular relationship is found to be significant is quite sensitive to the characteristics of study. Thus, researchers should be cautious in generalizing from the results of any specific analysis. In this paper, we check meta-analysis to control for the conditional factors and to draw general conclusions about privatization. However, our findings should be viewed within the context of the limitations endemic to the metaanalysis methodology. As in most meta-analyses (see García-Meca and SánchezBallesta, 2010), the problem of reverse causality -privatization affecting performance or performance affecting privatization- is not controlled for. Since the competition determine the expected performance improvements from privatization, further research on the roles of state Governments in competition and regulation should be considered.

Despite a large empirical literature about economic and political impact of the privatization, the research has not yet answered how the change of ownership impacts privatized firm's workers. The analysis of productivity of privatized firms let us know if employments levels remain stable or rise. However, it is difficult to predict whether a privatization process create or destroy jobs for an entire economy. Privatization generally causes the firm to reduce its direct employment levels, but the indirect effect of increased industrial dynamism may cause aggregate employment to increase. More research is needed to improve our understanding of this. Little research has analyzed privatization's impact on the level of development of a country. Privatization eases national budget constraints; however, the overall distributional impact on different groups of citizens cannot be measured. Other possible research avenues include the analysis of the privatization of recent nationalized financial entities, especially, European commercial banks. In the nineties, 250 commercial banks were fully or 
partially privatized by governments of 59 countries (Megginson, 2005), either IPOs or privately through an asset sale, because the state ownership was not working as planned. It is expected that governments decide to privatize these entities after having been rationalized to develop the financial system which promoted the economic growth and to recover the current financial aids given by Europe (Pina et al., 2016).

Empirical evidence suggests that the industry seems to play an important role for performance effects of privatizations. It is supposed that the relationship between privatization and firm performance is significantly stronger in competitive industries and the competition in the market can bring efficiency gains. Studies that cover the privatizations by industry can be useful to expand the research.

Overall, our findings suggest the need for a more contextual understanding of the firm performance phenomenon and the post-privatization benefits. The variance of the effect sizes further cautions researchers to be sensitive to consider a comprehensive set of positive and negative outcomes of privatizations.

\section{8.- Conclusions}

We conduct a meta-analysis to aggregate empirical evidence on the performance of privatized companies. The findings of the meta-regression show that the method of privatization is a determinant of the performance of privatized companies. Our results emphasize that companies privatized through public offering obtain a better performance than companies privatized using other methods, such as private sale or voucher privatization. In public offerings, legal and information requirements discipline quoted companies and obtain a bigger performance improvement. Our results do not support the common-place assumption that privatization in developing countries does 
not lead to improvements in financial performance. The effective liberalization processes in these countries that were linked to the change of ownership may explain why the performance of privatized firms improved more in developing than developed countries. 


\section{REFERENCES}

Alexandre, H. and G. Charreaux. 2004. Efficiency of French Privatizations, a Dynamic Vision. Journal of Corporate Finance 10, 467-94.

Arcas, M.J. and Bachiller, P. 2008. Performance and Capital Structure of Privatized Firms in Europe. Global Economic Review 37, 107-123.

Arcas, M.J. and Bachiller, P. 2010. Operating performance of privatized firms in Europe: organizational and environmental factors. International Journal of Public Administration 33, 487-498.

Ariff, M., Cabanda, E., and Sathye, M. 2009. Privatization and performance: evidence from telecommunications sector. Journal of the Operational Research Society, 60(10), 1315-1321.

Arocena, P. and D. Oliveros. 2012. The Efficiency of State-Owned and Privatized Firms, Does Ownership make a Difference? International Journal of Production Economics 140, 457-65.

Athanassopoulos, A. D., and Giokas, D. 1998. Technical efficiency and economies of scale in state owned enterprises: The Hellenic telecommunications organisation. European Journal of Operational Research, 107(1), 62-75.

Aussenegg, W., and Jelic, R. 2007. The operating performance of newly privatised firms in Central European transition economies. European Financial Management, 13(5), 853-879.

Bacchiocchi, E., M. Florio and M. Grasseni. 2005. The Missing Shock, The Macroeconomic Impact of British Privatizations. Applied Economics 37, 1585-96.

Bachiller, P. 2009. Effect of Ownership on Efficiency in Spanish Companies. Management Decision 47, 289-307.

Bachiller, P. 2012. The Impact of Privatization on Economic Performance in European Companies. Journal des Economistes et des Etudes Humaines, 18, 1-20.

Bachiller, P. 2016. Privatization in Central Government. In A. Farazmand, (coord.), Global Encyclopedia of Public Administration, Public Policy and Governance (pp. 1-9). New Delhi- Springer.

Banerjee, A. (2003): "Does Incentive Regulation "Cause" Degradation of Retail Telephone. Service Quality?"; Information Economics and Policy, Vol. 15, pp. 243269.

Bel, G. and X. Fageda. 2009. Factors Explaining Local Privatization, a Meta-Regression Analysis. Public Choice 139, 105-19. 
Ben Naceur, S., Ghazouani, S., and Omran, M. 2007. The performance of newly privatized firms in selected MENA countries: The role of ownership structure, governance and liberalization policies. International Review of Financial Analysis, 164. 332-353.

Boardman, A.E. and Vining, A.R. 1989. "Ownership and performance in competitive environments: A comparison of the performance of private, mixed and stateowned enterprises"; Journal of Law and Economics, 321. 1-33.

Boardman, E., C. Laurin and A. R. Vining. 2002. Privatization in Canada, Operating and Stock Price Performance with International Comparisons. Canadian Journal of Administrative Sciences 19, 137-54.

Boehmer, E., Nash, R. C., and Netter, J. M. 2005. Bank privatization in developing and developed countries: Cross-sectional evidence on the impact of economic and political factors. Journal of Banking and Finance, 29(8), 1981-2013.

Bortolotti, B., Fantini, M. and Siniscalco, D. 2003. "Privatisation around the world: evidence from panel data"; Journal of Public Economics, Elsevier, 88, 305-332.

Bortolotti, B., J. D’Souza, M. Fantini and W. L. Megginson. 2002. Privatization and the Sources of Performance Improvement in the Global Telecommunications Industry. Telecommunications Policy 26, 243-68.

Boubakri, N. and J. C. Cosset. 1998. Privatization in Developing Countries, an Analysis of the Performance of Newly Privatized Firms. The Journal of Finance 53, 1081110.

Boubakri, N., Cosset, J. C., and Guedhami, O. 2004. Privatization, corporate governance and economic environment: Firm-level evidence from Asia. PacificBasin Finance Journal, 12. 65-90.

Boubakri, N., Cosset, J. C., and Guedhami, O. 2005. Liberalization, corporate governance and the performance of privatized firms in developing countries. Journal of Corporate Finance, 11.767-790.

Boubakri, N., Cosset, J. C., and Guedhami, O. 2008. Privatisation in developing countries: Performance and ownership effects. Development Policy Review, 263. 275-308.

Boubakri, N., Cosset, J. C., and Saffar, W. 2013. The role of state and foreign owners in corporate risk-taking: Evidence from privatization. Journal of Financial Economics, 1083. 641-658. 
Boussofiane, a., S. Martin and D. Parker. 1997. The Impact on Technical Efficiency of the UK Privatization Programme. Applied Economics 29, 297-310.

Boutchkova, M. and W. Megginson. 2000. Privatization and the Rise of Global Capital Markets. Financial Management 29, 31-75.

Bozec, R., Dia, M., and Breton, G. 2006. Ownership-efficiency relationship and the measurement selection bias. Accounting and Finance, 46(5), 733-754.

Broadbent, J. and J. Guthrie. 1992. Changes in the Public Sector, a Review of Recent "alternative" Accounting Research. Accounting, Auditing and Accountability Journal 5, 3-31.

Cabeza, L. and Gómez, S. 2007. Governance and Performance of Spanish Privatised Firms. Corporate Governance, 15, 503-519.Cavaliere, A. and S. Scabrosetti. 2008. Privatization and Efficiency, From Principals and Agents to Political Economy. Journal of Economic Surveys 22, 685-710.

Chen, L., S. Li and W. Lin. 2007. Corporate Governance and Corporate Performance, Some Evidence from Newly Listed Firms on Chinese Stock Markets. International Journal of Accounting, Auditing and Performance Evaluation 4, 183-97.

Chong, A. and Galdo, V. 2006. "Streamlining and Privatization Prices in the Telecommunications Industry"; Economica, 73, 461-484.

Chong, a. and V. Galdo. 2007. Should State-Owned Firms Change CEOs before Privatization? some Evidence from the Telecommunications Industry. Applied Economics Letters 14, 591-5.

Claessens, S., and Djankov, S. (1999). Enterprise performance and management turnover in the Czech Republic. European Economic Review, 43(4), 1115-1124.

Corrado, R., and Zollo, M. 2006. Small worlds evolving: governance reforms, privatizations, and ownership networks in Italy. Industrial and Corporate Change, $15,319-352$.

Cragg, M. I. and I. J. A. Dyck. 1999. Management Control and Privatization in the United Kingdom. The Rand Journal of Economics 30, 475-97.

Cuervo, A. (2002): "Corporate governance Mechanisms: A plea for less code of good governance and more market control"; Corporate Governance an International Review, Vol. 10, No. 2, pp. 84-93.

D'Souza, J. and Megginson, W. 1999. "The financial and operating performance of privatized firms during the 1990s"; The Journal of Finance, 54, 1397-1438. 
D’Souza, J., Megginson, W. and Nash, R. 2001. "Determinants of Performance Improvements in Privatized Firms: The Role of Restructuring and Corporate Governance"; Working Paper, University of Oklahoma.

D’Souza, J., Megginson, W. and Nash, R. 2005. "Effect of institutional and firmspecific characteristics on post-privatization performance: Evidence from developed countries"; Journal of Corporate Finance, 11, 747-766.

Dewenter, K. L. and P. H. Malatesta. 1997. Public Offerings of State-Owned and Privately-Owned Enterprises, an International Comparison. The Journal of Finance 52, 1659-79.

Dewenter, K. L. and P. H. Malatesta. 2001. State-Owned and Privately Owned Firms: An Empirical Analysis of Profitability, Leverage, and Labor Intensity. The American Economic Review 91, 320-334.

Dharwadkar, R., G. George and P. Brandes. 2000. Privatization in Emerging Economies, an Agency Theory Perspective. Academy of Management Review 25, 650-69.

D'souza, J., R. Nash and W. Megginson. 2001. Determinants of Performance Improvements in Privatized Firms, The Role of Restructuring and Corporate Governance. Working Paper, University of Oklahoma .

Durant, R. F. and J. S. Legge Jr. 2002. Politics, Public Opinion, and Privatization in France, assessing the Calculus of Consent for Market Reforms. Public Administration Review 62, 307-323.

Durant, R. F. and J. S. Legge. 2001. Politics, Public Opinion, and Privatization, a Test of Competing Theories in Great Britain. Public Organization Review 1, 75-95.

Dyck, I. J. 1997. Privatization in Eastern Germany, Management Selection and Economic Transition. The American Economic Review 87, 565-97.

Eckel, C., D. Eckel and V. Singal. 1997. Privatization and Efficiency, Industry Effects of the Sale of British Airways. Journal of Financial Economics 43, 275-98.

Fan, J. P., Wong, T. J., and Zhang, T. 2007. Politically connected CEOs, corporate governance, and Post-IPO performance of China's newly partially privatized firms. Journal of Financial Economics, 842. 330-357.

Faraci, R. (2001): "The governance of privatized firms: a theoretical framework to explore environmental and organizational determinants of privatization and restructuring"; Paper submitted to the Business Policy and Strategy Division Academy of Management. 
Farinos, J. E., Garcia, C. J., and Ibanez, A. M. 2007. Operating and stock market performance of state-owned enterprise privatizations: the Spanish experience. International Review of Financial Analysis, 16(4), 367-389.

Feng, F., Sun, Q., and Tong, W. H. (2004). Do government-linked companies underperform?. Journal of Banking and Finance, 28(10), 2461-2492.

Frydman, R., a. Rapaczynski and J. S. Earle. 1993. The Privatization Process in Central Europe, Economic Environment, Legal and Ownership Structure, Institutions for State Regulation, Overview of Privatization Programs, Initial Transformation of Enterprises. Central European University Press.

Frydman, R., C. Gray, M. Hessel and A. Rapaczynski. 1999. When does Privatization Work? the Impact of Private Ownership on Corporate Performance in the Transition Economies. The Quarterly Journal of Economics 114, 1153-91.

García-Meca, E. and J. P. Sánchez-Ballesta. 2010. The Association of Board Independence and Ownership Concentration with Voluntary Disclosure, a MetaAnalysis. European Accounting Review 19, 603-27.

Gupta, N. 2005. Partial privatization and firm performance. The Journal of Finance, 60, 987-1015.

Harper, J.T. 2002. "The performance of privatized firms in the Czech Republic"; Journal of Banking and Finance, 26, 621-649.

Hernández de Cos, P., Arguimón, I. and González-Páramo, J.M. 2004. "Public ownership and business performance in the Spanish manufacturing sector, 19831996"; Public Finance Review, 32, 148-182.

Ho, J. L. Y., Yang, X., and Li, X. 2011. Control Privatization, Corporate Governance, and Firm Performance: Evidence from China. Journal of International Accounting Research, 10(2), 23-56.

Hodge, G. A. 2006. Privatization and Market Development, Global Movements in Public Policy Ideas. Edward Elgar Publishing.

Hunter, J. E. and Schmidt, F. L. (1990) Methods of Meta-analysis: Correcting Error and Bias in Research Findings (Beverly Hills, CA: Sage).

Jia, J., Sun, Q., and Tong, W. H. 2005. Privatization Through an Overseas Listing: Evidence from China's H Share Firms. Financial Management, 34(3), 5-30.

Jiang, G., Yue, H., and Zhao, L. 2009. A re-examination of China's share issue privatization. Journal of Banking and Finance, 33(12), 2322-2332. 
La Porta, R. and F. Lopez-de-Silanes. 1999. The Benefits of Privatization, Evidence from Mexico. The Quarterly Journal of Economics 114, 1193-242.

La Porta, R., Lopez de Silanes, F. and Shleifer, A. 2002. Government ownership of banks. The Journal of Finance, 57(1), 265-301.

La Porta, R., Lopez de Silanes, F., Shleifer, A. and Vishny, R.W. (2000): "Investor Protection and Corporate Governance," Journal of Financial Economics, Vol. 58, pp. 3-28.

Lane, J. E. 2000. New Public Management, an Introduction. Routledge.

Liao, L., Liu, B., and Wang, H. 2014. China's Secondary Privatization: Perspectives from the Split-Share Structure Reform. Journal of Financial Economics. Forthcoming

Lipsey, M.W. and Wilson, D.B. 2001. Practical Meta-Analysis. Thousand Oaks, California: Sage.

Loc, T. D., Lanjouw, G., and Lensink, R. 2006. The impact of privatization on firm performance in a transition economy. Economics of Transition, 142. 349-389.

Löffler, E. and T. Bovaird. 2009. Public Management and Governance. Routledge.

Mager, F., and Jesswein, T. 2009. The fundamental performance of newly privatized firms: evidence from continental Europe. Applied Economics Letters, 17(2), 181186.

Mangaran P. F. 2003. The Financial and Operational Performances of Privatized Banks: The Philippine Experience. Review of Pacific Basin Financial Markets and Policies, 6, 441-472.

Martin, S. and D. Parker. 1995. Privatization and Economic Performance Throughout the UK Business Cycle. Managerial and Decision Economics 16, 225-37.

Megginson, W. L. 2005. The Financial Economics of Privatization. Oxford University Press, USA.

Megginson, W. L. and N. L. Sutter. 2006. Privatisation in Developing Countries. Corporate Governance, an International Review 14, 234-65.

Megginson, W. L., and Netter, J. M. 2001. From state to market: A survey of empirical studies on privatization. Journal of Economic Literature, 39, 321-389.

Megginson, W. L., Morgan and L. Nail. 2004. The Determinants of Positive Long-Term Performance in Strategic Mergers, Corporate Focus and Cash. Journal of Banking and Finance 28, 523-52. 
Megginson, W.L., Nash, R.C. and Van Randenborgh, M. 1994. The Financial and Operating Performance of Newly Privatised Firms: An international Empirical Analysis; The Journal of Finance, Vol. XLIX, No.2, pp. 403-452.

Nestor, S. and Mahboobi, L. (2000): "Privatisation of public utilities: the OECD experience". En OECD: Privatisation Competition and Regulation, Paris.

Newbery, D. M. and M. G. Pollitt. 1997. The Restructuring and Privatisation of Britain's CEGB—was it Worth it? The Journal of Industrial Economics 45, 269303.

Odipo, M. 2010. Does the effect of government ownership affect financial performance? A survey of partially privatized firms listed at the Nairobi securities exchange. In Proceeding of the eight operations research society for eastern Africa ORSEA. International conference p. 286.OECD (1998): Corporate Governance, State-owned Enterprises and Privatisation. Paris OECD.

OECD (1998): Corporate Governance, State-owned Enterprises and Privatisation. Paris OCDE.

OECD (2001): Recent Privatisation Trends. Financial Markets Trends, No. 79.

Okten, C. and Arin, K.P. 2006. "The Effects of Privatization on Efficiency: How Does Privatization Work?”; World Development, 34, 1537-1556.

Omran, M. 2009. Post-Privatization Corporate Governance and Firm Performance, The Role of Private Ownership Concentration, Identity and Board Composition. Journal of Comparative Economics, 37, 658-73.

Parker, D. 1999. "The performance of BAA before and after privatization: a DEA study"; Journal of Transport Economics and Policy, 33, 133-146.

Parker, D. and K. Hartley. 2006. Do Changes in Organizational Status Affect Financial Performance? Strategic Management Journal 12, 631-41.

Pejovich, S. 2005. On the Privatization of" Stolen Goods" in Central and Eastern Europe. The Independent Review 10, 209-29.

Peters, B. 1996. The Future of Governing. Lawrence, University Press of Kansas.

Pina, V., Torres, L., and Bachiller, P. (2016). Political Influence and the Performance of Nonprofit Spanish Banks. Nonprofit Management and Leadership 26(4): 471-488.

Pollitt, C. and G. Bouckaert. 2000. Public Management Reform, a Comparative Analysis. Oxford University Press .

Prior, D. and J. Surroca. 2005. Innovación en los indicadores de análisis económico, aplicación de las empresas privatizadas. Revista de Contabilidad y Dirección 2, $147-75$. 
Qi, D., W. Wu and H. Zhang. 2000. Shareholding Structure and Corporate Performance of Partially Privatized Firms, Evidence from Listed Chinese Companies. PacificBasin Finance Journal 8, 587-610.

Ramamurti, R. 1997. Testing the Limits of Privatization, argentine Railroads. World Development 25, 1973-93.

Rodríguez, G. C., C. A. D. Espejo and R. V. Cabrera. 2007. Incentives Management during Privatization, an Agency Perspective. Journal of Management Studies 44, 536-60.

Romero-Martínez, A.M., Ortiz-de-Urbina-Criado, M. and Soriano, D.R. (2010), Evaluating European Union support for innovation in Spanish small and medium enterprises. Service Industries Journal, 30, 671-683.

Rosenbusch, N., Brinckmann, J., \& Müller, V. (2013). Does acquiring venture capital pay off for the funded firms? A meta-analysis on the relationship between venture capital investment and funded firm financial performance. Journal of Business Venturing, 28(3), 335-353.

Rosenthal, R. (1991) Meta-Analytic Procedures for Social Research. Newbury Park: Sage.

Sakr, A. 2014. The Impact of Privatisation on the Performance of Firms in Egypt. Research Journal of Finance and Accounting, 5(15), 73-81.

Stanley, T.D. and Doucouliagos, H. (2010) Picture this: A simple graph that reveals much ado about research. Journal of Economic Surveys, 24, 170-191.

Sueyoshi, T. 1998. Privatization of Nippon Telegraph and Telephone: Was it a good policy decision?; European Journal of Operational Research, 107, 45-61.

Sun, Q., and Tong, W. H. 2003. China share issue privatization: the extent of its success. Journal of financial economics, 70(2), 183-222.

Thatcher, M.E. and Pingry, D.E. (2004): "Understanding the business value of information technology investments: theoretical evidence from alternative market and cost structures"; Journal of Management Information Systems, Vol. 21, No.2, pp. 61-85.

Tian, L. 2001. "Government Shareholding and the Value of China";s Modern Firms"; Working Paper London Business School. August.

Tian, L. and S. Estrin. 2008. Retained State Shareholding in Chinese PLCs, Does Government Ownership always Reduce Corporate Value? Journal of Comparative Economics 36, 74-89. 
Torres, L. and V. Pina. 2002. Delivering Public Services-Mechanisms and Consequences, Changes in Public Service Delivery in the EU Countries. Public Money and Management 22, 41-8.

Tsai, H.C., Chen, C.M. y Tzeng, G.H. 2006. The comparative productivity efficiency for global telecoms; International Journal of Production Economics, 103, 509526.

Valickova, P., Havranek, T. and Horvath, R. 2014. Financial development and economic growth a meta-analysis. Journal of Economic Surveys doi: 10.1111/joes.12068.

Vickers, J. and G. Yarrow. 1988. Privatization, an Economic Analysis. The MIT Press Cambridge.

Vickers, J. and G. Yarrow. 1991. Economic Perspectives on Privatization. The Journal of Economic Perspectives 5, 111-32.

Villalonga, B. 2000. Privatization and Efficiency, Differentiating Ownership Effects from Political, Organizational, and Dynamic Effects. Journal of Economic Behavior and Organization 42, 43-74.

Vining, a. R. and A. E. Boardman. 1992. Ownership Versus Competition, Efficiency in Public Enterprise. Public Choice 73, 205-39.

Von Eije, H. and W. L. Megginson. 2008. Dividends and Share Repurchases in the European Union. Journal of Financial Economics 89, 347-74.

Wang, K., and Shailer, G. 2013. Ownership Concentration and Firm Performance in Emerging Markets: A Meta Analysis. Journal of Economic Surveys 29, pp. 199229.

Wei, Z., Varela, O., D'Souza, J., and Hassan, M. K. 2003. The financial and operating performance of China's newly privatized firms. Financial Management, 107-126.

Wu, H. L. 2006. The Policy-Fit View on the Efficiency Effects of Privatization. Journal of Policy Modeling 28, 281-92.

$\mathrm{Wu}, \mathrm{H}$. L. 2007. Exploring the sources of privatization-induced performance changes. Journal of Organizational Change Management, 201. 44-59.

Yarrow, G. 1999. A Theory of Privatization, Or Why Bureaucrats are Still in Business. World Development 27, 157-68.

Yarrow, G., M. King, J. Mairesse and J. Melitz. 1986. Privatization in Theory and Practice. Economic Policy 1, 324-77. 
Zahra, S. A., R. D. Ireland, I. Gutierrez and M. A. Hitt. 2000. Privatization and Entrepreneurial Transformation, Emerging Issues and a Future Research Agenda. Academy of Management Review 25, 509-24.

Zohlnhöfer, R., H. Obinger and F. Wolf. 2008. Partisan Politics, Globalization, and the Determinants of Privatization Proceeds in Advanced Democracies (1990-2000). Governance 21, 95-121. 